Article

\title{
Antioxidant Activity and Acteoside Analysis of Abeliophyllum distichum
}

\author{
Hak-Dong Lee ${ }^{1,+}{ }^{\dagger}$ Ji Hyun Kim ${ }^{2,+} \mathbb{C}$, Qi Qi Pang ${ }^{3}$, Pil-Mun Jung ${ }^{4}$, Eun Ju Cho ${ }^{3 \oplus \mathbb{C} \text { and }}$ \\ Sanghyun Lee ${ }^{1, * \mathbb{D}}$ \\ 1 Department of Plant Science and Technology, Chung-Ang University, Anseong 17546, Korea; \\ gkrehd1234@naver.com \\ 2 Department Food Science, Gyeongnam National University of Science and Technology, Jinju 52725, Korea; \\ jihyunkim@gntech.ac.kr \\ 3 Department Food Science and Nutrition, Pusan National University, Busan 46241, Korea; \\ pangqq@pusan.ac.kr (Q.Q.P.); ejcho@pusan.ac.kr (E.J.C.) \\ 4 Miseonnamu Products Co., Goesan 28035, Korea; kt123@hanmail.net \\ * Correspondence: slee@cau.ac.kr; Tel.: +82-31-670-4688 \\ + These authors have equally contributed to this research.
}

Received: 23 September 2020; Accepted: 17 November 2020; Published: 19 November 2020

check for updates

\begin{abstract}
This study determined acteoside and its content in Abeliophyllum distichum via HPLC/UV and LC/ESI-MS to obtain insights into the potential use of this plant as an antioxidant agent. Moreover, 1,1-diphenyl-2-picrylhydrazyl (DPPH), hydroxyl $\left({ }^{\bullet} \mathrm{OH}\right)$, and $\mathrm{O}_{2}{ }^{-}$radical scavenging activity assays were performed to assess in vitro antioxidative activity. The $\mathrm{DPPH},{ }^{\bullet} \mathrm{OH}$, and $\mathrm{O}_{2}{ }^{-}$radical scavenging activities of $A$. distichum leaf EtOH extracts at a $250 \mu \mathrm{g} / \mathrm{mL}$ concentration were $88.32 \%, 94.48 \%$, and $14.36 \%$, respectively, whereas those of stem extracts at the same concentration were $88.15 \%$, $88.99 \%$, and $15.36 \%$, respectively. The contents of acteoside in A. distichum leaves and stems were 162.11 and $29.68 \mathrm{mg} / \mathrm{g}$, respectively. Acteoside was identified as the main antioxidant compound in A. distichum leaves, which resulted in $\mathrm{DPPH},{ }^{\bullet} \mathrm{OH}$, and $\mathrm{O}_{2}{ }^{-}$radical scavenging activities of $82.84 \%$, $89.46 \%$, and $30.31 \%$, respectively, at a $25 \mu \mathrm{g} / \mathrm{mL}$ concentration. These results indicate that $A$. distichum leaves and stems containing the antioxidant acteoside can be used as natural ingredients for functional and nutritional supplements.
\end{abstract}

Keywords: Abeliophyllum distichum; acteoside; DPPH; hydroxyl radical; $\mathrm{HPLC} / \mathrm{UV} ; \mathrm{O}_{2}^{-}$radical

\section{Introduction}

Abeliophyllum distichum Nakai is an important plant resource and represents the only species within the genus Abeliophyllum in the world [1]. A. distichum is an endemic plant in Korea and is commonly referred to as white forsythia. Currently, this plant is protected and has been designated as an endangered plant species in Buan-, Goesan-, and Yeongdong-gun, Korea [2,3], with Goesan-gun being the main producer of this resource. Although it has been used as a landscape plant, A. distichum has also been found to possess therapeutic value due to its anti-cancer [4], anti-diabetic (via aldose reductase inhibition) [5], and anti-hypertensive properties [3]. A. distichum is known to contain some glycosides in its leaves including acteoside, isoacteoside, rutin, and hirsutrin [6], responsible for its anti-inflammatory [7], anti-nociceptive activities [8], and antioxidant activity [6,9,10], and it has also been reported to improve sexual function [11]. Acteoside, a commonly identified phenylpropanoid glycoside in plants [12], is a well-known antioxidant and was first isolated from Syringa vulgaris flowers [13]. Moreover, the crude ash contents of $A$. distichum leaves and stems are $1.32 \%$ and $0.91 \%$, respectively, and its fructose and glucose contents have been reported as 32.13 and $56.17 \mathrm{mg} / \mathrm{g}$ for the leaves, and 11.38 and $10.59 \mathrm{mg} / \mathrm{g}$ for the stems, respectively [14]. 
Free radicals have been linked to the onset of many adverse health effects such as aging, diabetes, cardiovascular, and neurodegenerative diseases [15]. Free radicals including $\mathrm{O}_{2}{ }^{-}$, hydroxyl $\left({ }^{\bullet} \mathrm{OH}\right)$, and singlet oxygen $\left({ }^{1} \mathrm{O}_{2}\right)$ are highly reactive in the body and produce reactive oxygen species (ROS) and other free radicals [15]. ROS deteriorate crucial biomolecules for biological functions such as lipids, proteins, DNA, and RNA, thereby leading to cell death and the loss of physiological functions in the body [16]. The 1,1-diphenyl-2-picrylhydrazyl (DPPH) radical is a stable free radical that exhibits a characteristic violet color when reduced by antioxidant materials. Therefore, it is widely used in measuring antioxidant activity [17]. The ${ }^{\bullet} \mathrm{OH}$ radical is generated from hydrogen peroxide $\left(\mathrm{H}_{2} \mathrm{O}_{2}\right)$ and $\mathrm{O}_{2}{ }^{-}$by Fenton reaction and is more strongly reactive with biological molecules than other radicals, resulting in many diseases [18]. The $\mathrm{O}_{2}{ }^{-}$is generated from molecular oxygen by reduction of one electron in the mitochondrial electron transport chain, endoplasmic reticulum, NADPH oxidase, cytochrome $\mathrm{P} 450$, and xanthine oxidase [19]. It is rapidly converted by superoxide dismutase into $\mathrm{H}_{2} \mathrm{O}_{2}$, which becomes a highly reactive ${ }^{\bullet} \mathrm{OH}$ radical in the presence of transition metals and peroxynitrite with nitric oxide [20].

ROS, also known as oxygen free radicals by characteristics of unpaired valence electrons or unstable bonds, are among the most important factors that lead to aging and other related diseases such as neurodegenerative diseases [15]. In normal cases, ROS are produced via cellular respiration, metabolic byproducts, enzymatic synthesis, and physical and chemical processes in the body, but they can be removed by the body's antioxidant system such as enzymatic defenses and antioxidant scavengers [21]. However, the incomplete reduction and overproduction of ROS during various physiological processes may lead to oxidative damage of the cells [22]. Therefore, research on antioxidants that can protect living organisms from ROS oxidation is being actively conducted, with a particular focus on naturally occurring antioxidant agents. Among various naturally occurring antioxidants, phenolic compounds are phytochemicals derived from various plants as a result of their secondary metabolism. In particular, many studies demonstrated that phenolic compounds possess various pharmacological properties including anti-aging, anti-neurodegenerative, and anti-cancer activities, by their antioxidant activity counteracts the effects of ROS in the body [23].

In this study, ethanolic (EtOH) extracts were investigated to determine their acteoside distribution and quantify their content in A. distichum via high-performance liquid chromatography (HPLC) coupled with ultraviolet-visible (UV) and electrospray ionization (ESI) ion trap mass spectrometry (MS) detection. Bioactivity of the extracts and acteoside was evaluated by assessing the antioxidant capacity of the A. distichum extracts.

\section{Materials and Methods}

\subsection{Plant Materials and Isolation of Acteoside}

A. distichum leaves and stems were obtained from Miseonnamu Products Co., Goesan, Korea. A voucher specimen (No. LEE19-01) was deposited at the Department of Plant Science and Technology Herbarium, Chung-Ang University, Korea. Dried leaves (300 g) of A. distichum were extracted with $\mathrm{EtOH}$ for $3 \mathrm{~h}$ under reflux and were repeated 3 times. The EtOH extract $(120 \mathrm{~g})$ was concentrated, suspended in distilled water, and sequentially partitioned with $n$-hexane $(8 \mathrm{~g})$, chloroform (11 g), ethyl acetate $(29 \mathrm{~g})$, and $n$-butanol $(75 \mathrm{~g})$. A portion of the $n$-butanol fraction $(20 \mathrm{~g})$ was subjected to open column chromatography. The column was eluted with a stepwise gradient of chloroform and methanol. The sub-fractions were analyzed by TLC, and the dried residue was further purified with Sephadex LH-20 column chromatography. Fractions of similar composition as determined by TLC were pooled and acteoside (yield, $0.8 \%$ ) (Figure 1 ) was obtained by methanol $(\mathrm{MeOH})$ recrystallization. TLC was carried out on pre-coated silica gel $60 \mathrm{~F}_{254}$ plates (Merck), developed with chloroform-methanol-water (5.5:4.5:0.2). Open column chromatography was performed on a silica gel column (60-200 mesh, Zeochem) and Sephadex LH-20 (Sigma Aldrich). The purity of acteoside was $98 \%$ as determined by HPLC analysis. 
<smiles>C[C@H]1O[C@H](O[C@H]2[C@H](O)C(OCCc3ccc(O)c(O)c3)O[C@@H](CO)[C@@H]2OC(=O)/C=C/c2ccc(O)c(O)c2)[C@H](O)[C@@H](O)[C@@H]1O</smiles>

Figure 1. Chemical structure of acteoside.

\subsection{Instruments, Chemicals and Reagents}

DPPH and 2-deoxy-ribose were purchased from Sigma (St. Louis, MO, USA), $\mathrm{FeSO}_{4} \bullet 7 \mathrm{H}_{2} \mathrm{O}-\mathrm{EDTA}$ was purchased from Daejung Chemicals and Metals Co. Ltd. (Siheung, Korea), and $\mathrm{H}_{2} \mathrm{O}_{2}$ was obtained from Junsei (Tokyo, Japan). EDTA disodium salt dehydrate was obtained from Samchun Pure Chemical Co. Ltd. (Pyeongtaek, Korea), thiobarbituric acid (TBA) was purchased from Acros Organics (Fair Lawn, NJ, USA), and trichloroacetic acid (TCA) was purchased from Kanto Chemical Co. Inc (Tokyo, Japan). To measure $\mathrm{O}_{2}{ }^{-}$radical scavenging activity, Tris was purchased from LPS Solution (Daejeon, Korea), and phenazine methosulfate (PMS), NADH disodium salt, and nitrotetrazolium blue chloride (NBT) were purchased from Bio Basic Co. (Toronto, Canada). Chromatographic analysis was performed using an HPLC system (Agilent 1260 Infinity II Quat Pump, Santa Clara, CA, USA), equipped with a pump, auto-sampler, and diode array detector (DAD WR detector, Arcade, NY, USA). An Ultimate 3000RS system (Thermo Fisher Scientific Inc., Waltham, MA, USA), equipped with an autosampler and PDA-UV detector was used. Mass spectrometric analyses were performed using a Thermo Finnigan LTQ XL ion trap mass spectrometer, with an electrospray ionization (ESI) interface. HPLC grade solvents such as $\mathrm{H}_{2} \mathrm{O}, \mathrm{MeOH}$, and acetonitrile (ACN) were obtained from J. T. Baker (Phillipsburg, PA, USA). Acetic acid $(99.7 \%)$ was obtained from Samchun Pure Chemicals (Pyeongtaek, Korea).

\subsection{Preparation of Sample and Standard Solutions for HPLC}

The crude EtOH extract ( $20 \mathrm{mg}$ ) of $A$. distichum leaves and stems were dissolved in $1 \mathrm{~mL} \mathrm{MeOH}$ and filtered using a syringe filter $(0.45 \mu \mathrm{m})$. A stock solution of the standard compound was prepared by dissolving $1 \mathrm{mg}$ of acteoside in $1 \mathrm{~mL} \mathrm{MeOH}$. To construct an acteoside calibration curve, working solutions were prepared by diluting the stock solution to the desired concentrations.

\subsection{DPPH Radical Scavenging Activity}

DPPH radical scavenging activity was measured as described by Hatano et al. [24]. The A distichum $\mathrm{EtOH}$ extract and acteoside were first dissolved in $\mathrm{EtOH}$. The samples were then mixed into a $60-\mu \mathrm{M}$ DPPH solution in 96-well plates, then incubated in the dark at room temperature. After $30 \mathrm{~min}$, absorbance at $540 \mathrm{~nm}$ was measured with a microplate reader using L-ascorbic acid as a positive control. DPPH radical scavenging activity was calculated as follows:

$$
\text { DPPH radical scavenging activity }(\%)=\left(\mathrm{Abs}_{\mathrm{c}}-\mathrm{Abs}_{\mathrm{s}}\right) / \mathrm{Abs}_{\mathrm{c}} \times 100
$$

$\mathrm{Abs}_{\mathrm{c}}$ : Control absorbance, $\mathrm{Abs}_{\mathrm{s}}$ : Sample absorbance. 


\section{5. •OH Radical Scavenging Activity}

- $\mathrm{OH}$ radical scavenging activity was measured via Fenton reaction [25]. The A. distichum $\mathrm{EtOH}$ extract and acteoside were dissolved in phosphate-buffered saline, then mixed with $10 \mathrm{mM}$ $\mathrm{FeSO}_{4}{ }^{\circ} 7 \mathrm{H}_{2} \mathrm{O}$-EDTA, $10 \mathrm{mM}$ 2-deoxyribose, and $10 \mathrm{mM} \mathrm{H}_{2} \mathrm{O}_{2}$. The mixtures were incubated at $37^{\circ} \mathrm{C}$ in the dark for $4 \mathrm{~h}$, after which 1\% TBA and $2.8 \%$ TCA solutions were added, and the mixtures were heated to $100{ }^{\circ} \mathrm{C}$ for $20 \mathrm{~min}$. After cooling, the absorbance was measured at $490 \mathrm{~nm}$ using a microplate reader. L-ascorbic acid was used as a positive control. ${ }^{\bullet} \mathrm{OH}$ radical scavenging activity was calculated as follows:

$$
\cdot \mathrm{OH} \text { radical scavenging activity }(\%)=\left(\mathrm{Abs}_{\mathrm{c}}-\mathrm{Abs}_{\mathrm{s}}\right) / \mathrm{Abs}_{\mathrm{c}} \times 100
$$

$\mathrm{Abs}_{\mathrm{c}}$ : Control absorbance, $\mathrm{Abs}_{\mathrm{s}}$ : Sample absorbance.

\section{6. $\mathrm{O}_{2}^{-}$Radical Scavenging Activity}

$\mathrm{O}_{2}{ }^{-}$radical scavenging activity was assessed according to Ewing and Janero et al. [26]. A. distichum samples and acteoside diluted in $\mathrm{H}_{2} \mathrm{O}$ were mixed with $0.1 \mathrm{M}$ Tris- $\mathrm{HCl}$ (pH 7.4), 100 PMS, 500 NBT, and $500 \mu \mathrm{M} \mathrm{NADH}$, and incubated at room temperature without light. After $10 \mathrm{~min}$, the absorbance was measured at $560 \mathrm{~nm}$ using a microplate reader. L-ascorbic acid was used as a positive control. $\mathrm{O}_{2}{ }^{-}$radical scavenging activity was calculated as follows:

$$
\mathrm{O}_{2}{ }^{-} \text {radical scavenging activity }(\%)=\left(\mathrm{Abs}_{\mathrm{c}}-\mathrm{Abs}_{\mathrm{s}}\right) / \mathrm{Abs}_{\mathrm{c}} \times 100
$$

$\mathrm{Abs}_{\mathrm{c}}$ : Control absorbance, Abss: Sample absorbance.

\subsection{HPLC/UV and LC/ESI-MS Conditions}

Quantitative analysis of acteoside was performed using a reverse-phase HPLC system with an INNO C18 column $(25 \mathrm{~cm} \times 4.6 \mathrm{~mm}, 5 \mu \mathrm{m})$. The injection volume was $10 \mu \mathrm{L}$ and was monitored at $330 \mathrm{~nm}$. The column temperature was maintained at $25^{\circ} \mathrm{C}$ and the flow rate was set at $0.7 \mathrm{~mL} / \mathrm{min}$. A gradient elution system of the mobile phase was composed of $0.5 \%$ acetic acid in $\mathrm{H}_{2} \mathrm{O}(\mathrm{A})$ and $\mathrm{ACN}(\mathrm{B})$. The elutions were conducted as follows: $90 \% \mathrm{~A}$ at $0 \mathrm{~min}$, followed by $80 \%$ A from 0 to $10 \mathrm{~min}$, then $70 \%$ A from 10 to $15 \mathrm{~min}, 50 \%$ A from 15 to $20 \mathrm{~min}$, and $0 \%$ A from 20 to $30 \mathrm{~min}$, then maintained for $35 \mathrm{~min}$, increased to $90 \%$ A from 35 to $40 \mathrm{~min}$, and maintained for $45 \mathrm{~min}$. Regarding the LC/ESI-MS analyses, a Cortecs UPLC T3 column $(15 \mathrm{~cm} \times 2.1 \mathrm{~mm}, 1.6 \mu \mathrm{m})$ was used for chromatographic separations. The injection volume was $5 \mu \mathrm{L}$ and the flow rate was set at $250 \mu \mathrm{L} / \mathrm{min}$. The mobile phase consisted of $0.1 \%$ formic acid in $\mathrm{H}_{2} \mathrm{O}(\mathrm{A})$ and $\mathrm{ACN}(\mathrm{B})$. The elutions were conducted as follows: $90 \% \mathrm{~A}$ at $0 \mathrm{~min}$, followed by $80 \%$ A from 0 to $10 \mathrm{~min}$, then $70 \%$ A from 10 to $15 \mathrm{~min}, 50 \%$ A from 15 to $20 \mathrm{~min}$, $0 \%$ A from 20 to $25 \mathrm{~min}$ and maintained for $26 \mathrm{~min}$, then increased to $90 \%$ A between 26 and $26.5 \mathrm{~min}$ and maintained for $30 \mathrm{~min}$. Ionization of analytes was conducted using a negative mode of ESI. The capillary temperature was maintained at $320^{\circ} \mathrm{C}$; the ion source voltage was set at $3.5 \mathrm{kV}$, and the sheath gas was set at $42 \mathrm{arb}$. The capillary voltage was set at $10 \mathrm{~V}$ in negative mode. The average scan time was $0.01 \mathrm{~min}$ while the average time to change polarity was $0.02 \mathrm{~min}$. The collision energy was generally chosen to maintain an approximately $35 \%$ abundance of the precursor ion.

\subsection{Calibration Curve}

Calibration curves were constructed by plotting the concentrations of the standard solutions with their respective peak areas. The linearity of the calibration curve was determined based on the correlation coefficient $\left(r^{2}\right)$, after which the acteoside concentrations in the samples were calculated from the calibration curve. The calibration functions were determined based on the peak area $(Y)$, concentration $(X, \mathrm{mg} / \mathrm{mL})$, and mean values $(n=5) \pm$ standard deviation (SD). 


\subsection{Statistical Analysis}

All results were reported as the mean \pm SD. Statistical significance $(p<0.05)$ was determined via analysis of variance (ANOVA) followed by Duncan's multiple test using the Statistical Package for the Social Sciences (SPSS, Chicago, IL, USA) program.

\section{Results and Discussion}

The body has natural antioxidant systems such as antioxidant enzymes and antioxidant scavengers [27]. Antioxidant enzymes such as superoxide dismutase, glutathione peroxidases, and catalase have an antioxidant defense by detoxifying ROS [28]. In addition, antioxidant scavengers from dietary origin include tocopherol, ascorbic acid, and polyphenols, which play an important role in ROS detoxification [27]. Therefore, many researchers have focused on the development and identification of natural antioxidant products. A number of studies have reported antioxidant activity of natural products such as flavonoids by measuring their in vitro $\mathrm{DPPH},{ }^{\bullet} \mathrm{OH}$, and $\mathrm{O}_{2}{ }^{-}$radical scavenging activity $[29,30]$. In this study, we identified a flavonoid from A. distichum and also evaluated the in vitro antioxidant activities of its extracts as well as its active compound, acteoside.

Table 1 summarizes the $\mathrm{DPPH},{ }^{\bullet} \mathrm{OH}$, and $\mathrm{O}_{2}{ }^{-}$radical scavenging activity of the $\mathrm{EtOH}$ extracts from A. distichum leaves and stems at various concentrations $(5-250 \mu \mathrm{g} / \mathrm{mL})$. A. distichum extract treatments increased the DPPH radical scavenging activity in a dose-dependent manner. The leaves and stems of $A$. distichum at a $50 \mu \mathrm{g} / \mathrm{mL}$ concentration exhibited $84.50 \%$ and $67.30 \%$ activities, respectively. In addition, the $\mathrm{IC}_{50}$ values against DPPH of leaves and stems from A. distichum were 19.03 and $21.77 \mu \mathrm{g} / \mathrm{mL}$, respectively, indicating that the leaves of $A$. distichum possessed higher DPPH radical scavenging activity than its stems. Moreover, the ${ }^{\bullet} \mathrm{OH}$ radical scavenging activity of $A$. distichum leaves and stems exceeded $80 \%$ in all concentrations. Particularly, leaf extracts of $A$. distichum exceeding $50 \mu \mathrm{g} / \mathrm{mL}$ concentrations exhibited ${ }^{\bullet} \mathrm{OH}$ radical scavenging activity higher than $90 \%$, which was higher than that of the stem extracts. Previous studies reported that leaf extracts exerted stronger in vitro antioxidant activity than that of stem extracts [29,31]. The $\mathrm{O}_{2}{ }^{-}$radical scavenging activity of A. distichum leaves and stems was lower than that of the $\mathrm{DPPH}$ and ${ }^{\bullet} \mathrm{OH}$ radicals. A. distichum leaves and stem extracts exhibited $\mathrm{O}_{2}{ }^{-}$radical scavenging activity at 100 and $50 \mu \mathrm{g} / \mathrm{mL}$, respectively.

Table 1. DPPH, $\bullet \mathrm{OH}$, and $\mathrm{O}_{2}{ }^{-}$radical scavenging activities of $A$. distichum leaf and stem EtOH extracts.

\begin{tabular}{|c|c|c|c|c|c|c|}
\hline \multirow{2}{*}{$\begin{array}{c}\text { Treatment } \\
(\mu \mathrm{g} / \mathrm{mL})\end{array}$} & \multicolumn{2}{|c|}{ DPPH (\%) } & \multicolumn{2}{|c|}{ •OH (\%) } & \multicolumn{2}{|c|}{$\mathrm{O}_{2}^{-}(\%)$} \\
\hline & Leaves & Stems & Leaves & Stems & Leaves & Stems \\
\hline 5 & $15.40 \pm 2.74 \mathrm{e}$ & $23.30 \pm 2.26^{f}$ & $83.84 \pm 0.38^{d}$ & $82.83 \pm 0.31^{\mathrm{d}}$ & - & - \\
\hline 10 & $35.86 \pm 3.81^{d}$ & $34.37 \pm 3.51^{\mathrm{e}}$ & $87.47 \pm 0.42^{c}$ & $87.21 \pm 0.32^{c}$ & - & - \\
\hline 25 & $75.29 \pm 3.31^{c}$ & $61.74 \pm 1.25^{\mathrm{d}}$ & $89.79 \pm 0.47^{b}$ & $88.52 \pm 0.46^{b}$ & - & - \\
\hline 50 & $84.50 \pm 0.97^{b}$ & $67.30 \pm 1.03^{c}$ & $90.12 \pm 0.18^{b}$ & $89.39 \pm 0.49^{a}$ & - & $0.93 \pm 3.83^{c}$ \\
\hline 100 & $81.71 \pm 1.51^{b}$ & $71.76 \pm 1.38^{b}$ & $90.13 \pm 1.10^{b}$ & $89.62 \pm 1.34^{\mathrm{a}}$ & $9.89 \pm 0.98^{b}$ & $10.46 \pm 2.02^{b}$ \\
\hline 250 & $88.32 \pm 2.18^{a}$ & $88.15 \pm 3.56^{a}$ & $94.48 \pm 0.54^{\mathrm{a}}$ & $88.99 \pm 0.26^{\mathrm{a}, \mathrm{b}}$ & $14.36 \pm 0.97^{\mathrm{a}}$ & $15.36 \pm 1.99^{a}$ \\
\hline
\end{tabular}

The values represent the mean \pm SD. Different letters $\left({ }^{\mathrm{a}-\mathrm{f}}\right)$ indicate significant differences $(p<0.05)$, as determined by Duncan's multiple range test.

Acteoside was isolated from the $n$-butanol fraction of A. distichum. As depicted in the ${ }^{1} \mathrm{H}-\mathrm{NMR}$ spectrum, typical patterns of 3,4-dihydroxyphenyl (6.17-7.47 ppm) and rhamnosyl (0.95 ppm) moieties of acteoside were observed (NMR not shown). A total ionization chromatogram in the negative mode revealed the presence of acteoside $(\mathrm{m} / \mathrm{z} 624)$ at a retention time of $2.1 \mathrm{~min}$ in A. distichum leaves as a major metabolite (Figure 2). 

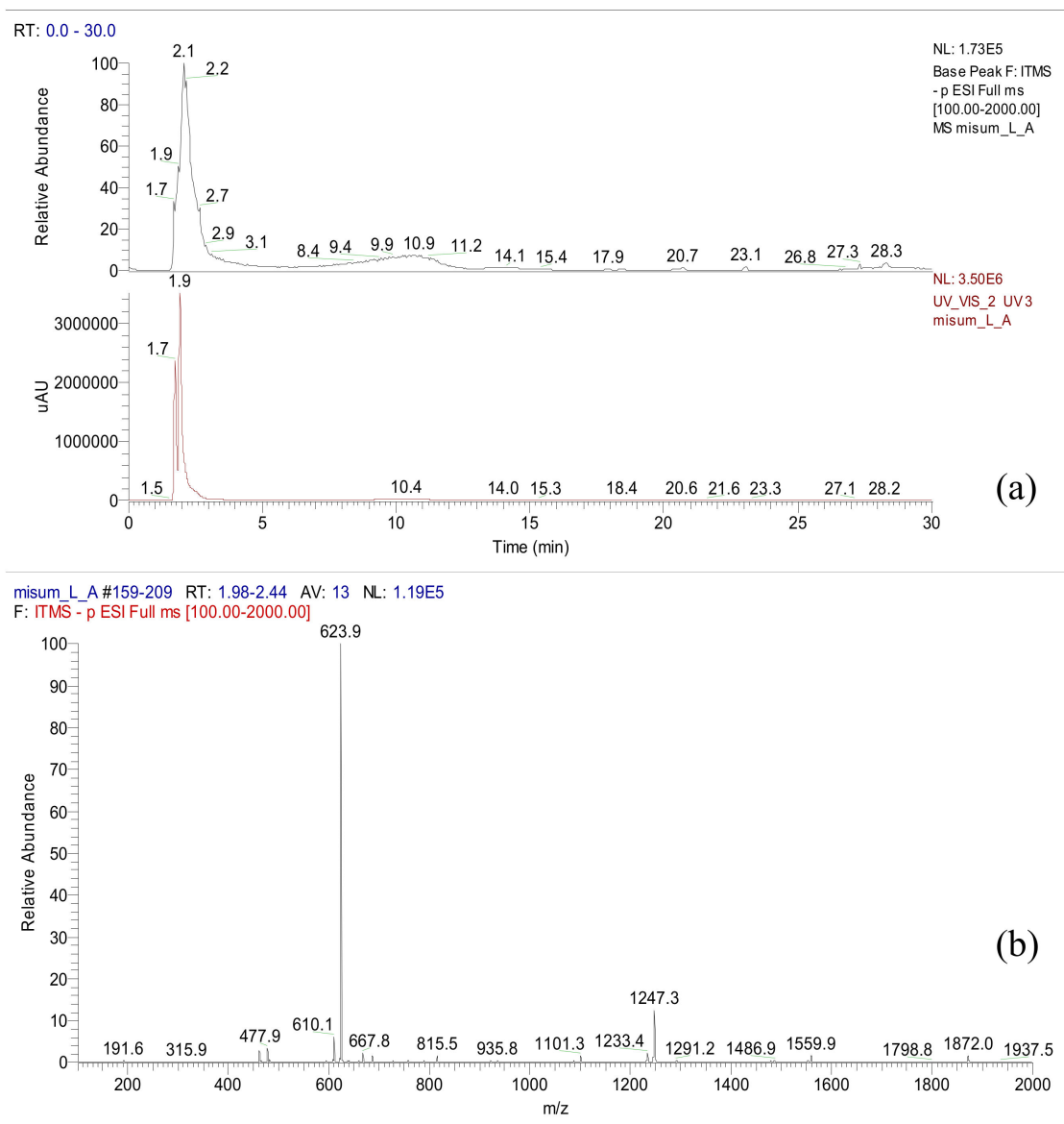

Figure 2. LC/ESI-MS data of A. distichum (LC chromatogram (a) and ESI-MS data (b)).

As shown in Table 2, the in vitro antioxidant activity of acteoside derived from A. distichum and L-ascorbic acid $(1-25 \mu \mathrm{g} / \mathrm{mL})$ were characterized by measuring their $\mathrm{DPPH},{ }^{\bullet} \mathrm{OH}$, and $\mathrm{O}_{2}{ }^{-}$ radical scavenging activities. Acteoside significantly increased DPPH radical scavenging activity in a dose-dependent manner. Particularly, an acteoside concentration of $25 \mu \mathrm{g} / \mathrm{mL}$ resulted in a DPPH radical scavenging activity of $82.83 \%$. The $\mathrm{IC}_{50}$ values for acteoside and L-ascorbic acid were 4.28 and $0.16 \mu \mathrm{g} / \mathrm{mL}$, respectively, in DPPH radical scavenging activity. Moreover, the ${ }^{\bullet} \mathrm{OH}$ radical scavenging activities for acteoside and L-ascorbic acid at $2.5 \mu \mathrm{g} / \mathrm{mL}$ were $89.46 \%$ and $89.95 \%$, respectively. Meanwhile, the $\mathrm{IC}_{50}$ values of acteoside and L-ascorbic acid were 0.22 and $0.48 \mu \mathrm{g} / \mathrm{mL}$, respectively, indicating that $A$. distichum-derived acteoside possessed a strong ${ }^{\bullet} \mathrm{OH}$ radical scavenging activity. Furthermore, acteoside from $A$. distichum also dose-dependently enhanced $\mathrm{O}_{2}{ }^{-}$radical scavenging activity. Moreover, acteoside and L-ascorbic acid at $25 \mu \mathrm{g} / \mathrm{mL}$ exhibited $\mathrm{O}_{2}{ }^{-}$radical scavenging activities of $30.31 \%$ and $17.68 \%$, respectively, indicating a strong acteoside-mediated $\mathrm{O}_{2}{ }^{-}$radical scavenging activity. A previous study reported that the antioxidant properties of acteoside were likely due to its hydroxyphenylethyl and caffeoyl moieties [32]. It was found to decrease oxidative stress by inhibiting free radicals and lipid peroxidation [30,32]. Furthermore, acteoside attenuated oxidative stress-induced neuronal apoptosis via inhibition of ROS levels and activation of the Nrf2 pathway $[33,34]$. In previous studies $[35,36]$, compounds such as phenolic glucosides having similar structures to that of acteoside exhibited similar antioxidant activities. 
Table 2. DPPH, ${ }^{\bullet} \mathrm{OH}$, and $\mathrm{O}_{2}{ }^{-}$radical scavenging activities of $A$. distichum-derived acteoside.

\begin{tabular}{ccccccc}
\hline \multirow{2}{*}{$\begin{array}{c}\text { Treatment } \\
(\mu \mathrm{g} / \mathrm{mL})\end{array}$} & \multicolumn{2}{c}{ DPPH (\%) } & \multicolumn{2}{c}{$\cdot \mathbf{O H}(\%)$} & \multicolumn{2}{c}{$\mathbf{O}_{\mathbf{2}}^{-} \mathbf{( \% )}$} \\
\cline { 2 - 6 } & Acteoside & $\begin{array}{c}\text { L-Ascorbic } \\
\text { Acid }\end{array}$ & Acteoside & $\begin{array}{c}\text { L-Ascorbic } \\
\text { Acid }\end{array}$ & Acteoside & $\begin{array}{c}\text { L-Ascorbic } \\
\text { Acid }\end{array}$ \\
\hline 1 & $15.60 \pm 2.00^{\mathrm{e}}$ & $70.04 \pm 3.40^{\mathrm{c}}$ & $62.40 \pm 0.84^{\mathrm{e}}$ & $56.92 \pm 1.31^{\mathrm{e}}$ & $3.60 \pm 0.18^{\mathrm{d}}$ & $6.63 \pm 1.82^{\mathrm{c}}$ \\
2.5 & $33.12 \pm 2.19^{\mathrm{d}}$ & $82.94 \pm 3.60^{\mathrm{b}}$ & $80.41 \pm 0.27^{\mathrm{d}}$ & $68.94 \pm 0.95^{\mathrm{d}}$ & $9.44 \pm 0.95^{\mathrm{c}}$ & $6.66 \pm 2.24^{\mathrm{c}}$ \\
5 & $59.90 \pm 1.76^{\mathrm{c}}$ & $94.15 \pm 2.73^{\mathrm{a}}$ & $86.08 \pm 0.11^{\mathrm{c}}$ & $73.29 \pm 1.67^{\mathrm{c}}$ & $9.89 \pm 0.38^{\mathrm{c}}$ & $7.20 \pm 1.76^{\mathrm{c}}$ \\
10 & $76.25 \pm 3.32^{\mathrm{b}}$ & $93.63 \pm 2.14^{\mathrm{a}}$ & $87.52 \pm 0.27^{\mathrm{b}}$ & $80.30 \pm 1.05^{\mathrm{b}}$ & $15.71 \pm 0.61^{\mathrm{b}}$ & $10.43 \pm 2.80^{\mathrm{b}}$ \\
25 & $82.84 \pm 1.65^{\mathrm{a}}$ & $94.74 \pm 3.60^{\mathrm{a}}$ & $89.46 \pm 0.85^{\mathrm{a}}$ & $89.95 \pm 0.47^{\mathrm{a}}$ & $30.31 \pm 0.34^{\mathrm{a}}$ & $17.68 \pm 3.62^{\mathrm{a}}$ \\
\hline
\end{tabular}

The values represent the mean \pm SD. Different letters $\left.{ }^{(-e-e}\right)$ indicate significant differences $(p<0.05)$, as determined by Duncan's multiple range test. L-Ascorbic acid was used as a positive control.

Our study investigated the acteoside contents of A. distichum leaves and stems via HPLC-UV analysis. Good separations were observed in the HPLC chromatogram with retention time detected at $19.26 \mathrm{~min}$. The HPLC conditions and the results of acteoside quantification are illustrated in Figure 3.
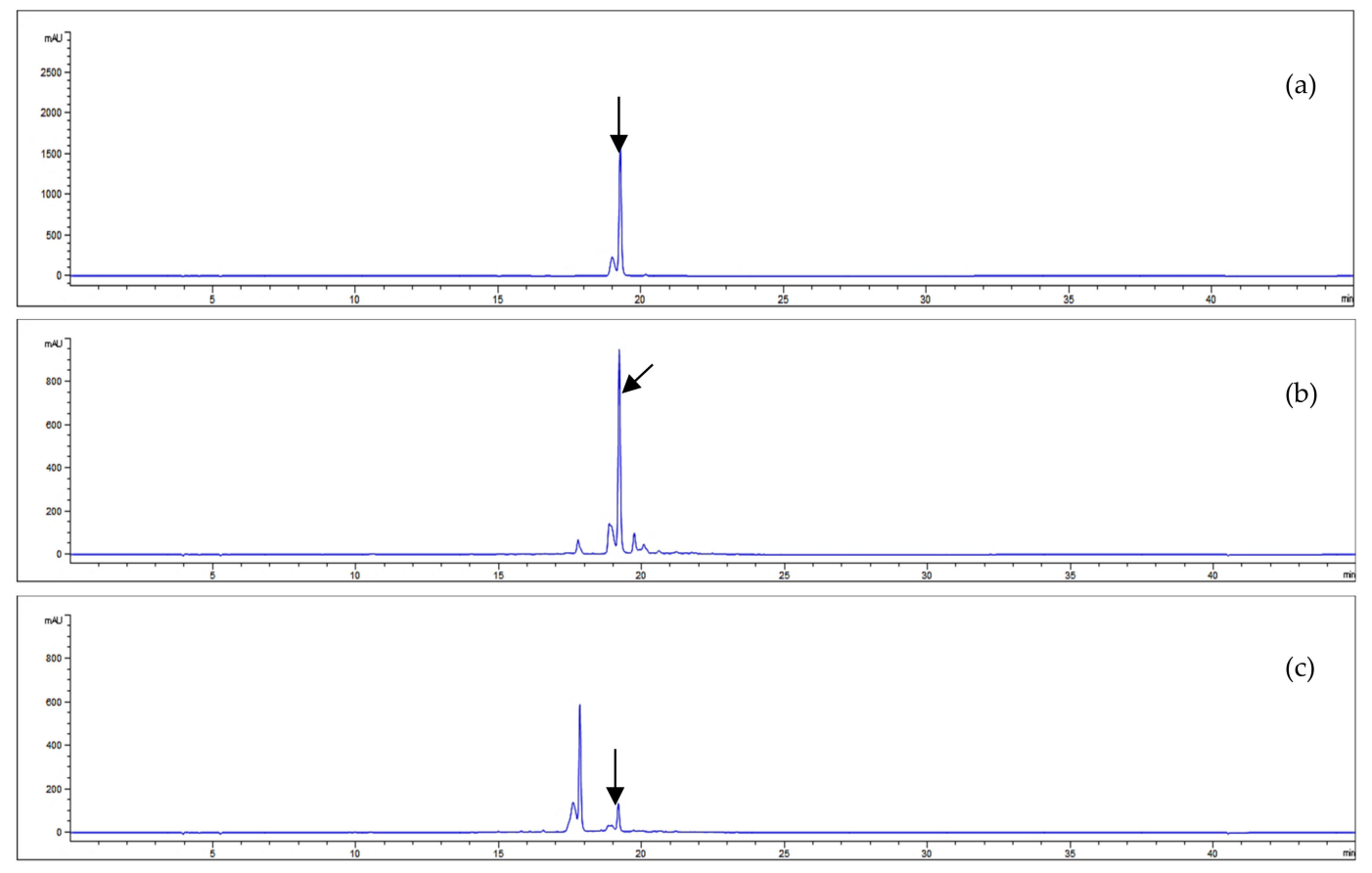

Figure 3. HPLC chromatograms of acteoside (a) and the EtOH extracts from A. distichum leaves (b) and stems $(\mathbf{c})(330 \mathrm{~nm})$.

The equation of the standard curve linear calibration was $Y=34,674 X-50,661$, where $Y$ represents a given peak area and $\mathrm{X}$ is the corresponding acteoside concentration. The analytical method used showed good linearity with a correlation coefficient $\left(r^{2}\right)$ greater than 0.999 (Table 3 ). The amount of acteoside present in each sample was calculated from the calibration curve. Figure 3 illustrates the chromatographic separation of acteoside and the $\mathrm{EtOH}$ extract of A. distichum and the results of the quantitative analyses are summarized in Table 3.

Table 3. Calibration curve and content of acteoside.

\begin{tabular}{cccccc}
\hline \multirow{2}{*}{ Compound } & $\mathbf{t}_{\mathbf{R}}{ }^{\mathbf{a}}$ & Calibration Equation $^{\mathbf{b}}$ & ${\text { Correlation Factor, } \boldsymbol{r}^{2} \mathbf{c}}_{$\cline { 4 - 5 }$}$ & & \multicolumn{2}{c}{ Content (mg/g Extract) } \\
\hline Acteoside & 19.26 & $\mathrm{Y}=34,674 \mathrm{X}-50,661$ & 0.999 & $162.11 \pm 0.63$ & $29.68 \pm 0.60$ \\
\hline
\end{tabular}

${ }^{\mathrm{a}} \mathrm{t}_{\mathrm{R}}=$ retention time. ${ }^{\mathrm{b}} \mathrm{Y}=$ peak area, $\mathrm{X}=$ concentration of standard $(\mathrm{mg} / \mathrm{mL}){ }^{\mathrm{c}} r^{2}=$ correlation coefficient for three data points in the calibration curve. 
Our results revealed that the content of phenolic glycosides in A. distichum extracts varied depending on the anatomical structure analyzed. Specifically, the leaf acteoside content $(162.11 \mathrm{mg} / \mathrm{g})$ was higher than that in the stems (Table 3). There are similar reports about acteoside content of A. distichum from $\mathrm{H}_{2} \mathrm{O}$ extract $(171.3 \mathrm{mg} / \mathrm{g}), 50 \%$ prethanol A extract $(240.1 \mathrm{mg} / \mathrm{g}), 70 \%$ prethanol A extract $(269.4 \mathrm{mg} / \mathrm{g})$, and $100 \%$ prethanol A extract $(326.1 \mathrm{mg} / \mathrm{g})$ [37]. Moreover, the total phenolic compounds and flavonoid contents of A. distichum were 50.64 and $96.47 \mathrm{mg} / \mathrm{g}$ in leaves and 13.53 and $18.53 \mathrm{mg} / \mathrm{g}$ in stems, respectively [14]. Phenolic glycosides, which belong to a group of natural substances with variable phenolic structure, are found in fruits, bark roots, grains, vegetables, and wine. A. distichum contains various active glycosides, such as acteoside, eutigoside $\mathrm{B}$, isoacteoside, rutin, hirsutism, and cornoside [5]. In a previous study, a phenolic glycoside identified as acteoside was found as the main compound present in A. distichum leaves [3]. The said compound is reported to possess various biological activities [38]. Our study utilized different assays to measure the antioxidant activities of different parts of $A$. distichum. The design of the study further assessed whether antioxidant activities could vary depending on the plant part containing the active compound.

The previous studies reported the antioxidant activity of $A$. distichum. The callus and flowers of A. distichum showed antioxidant activity by radical scavenging activities [39]. In addition, $A$. distichum protected DNA from oxidative stress in the oxidative damage-induced skin fibroblast cells [40]. Furthermore, acteoside isolated from $A$. distichum alleviated oxidative stress-induced cellular damage by decreasing the levels of phosphorylated p53 and $\gamma-\mathrm{H} 2 \mathrm{AX}$ in skin fibroblast cells [41]. A. distichum leaves and stems were found to be particularly valuable due to their high content of acteoside, which has therapeutic qualities. Therefore, A. distichum could be potentially used as a novel health supplement or in natural medicinal products and antioxidant beverages.

\section{Conclusions}

The antioxidant activity of $A$. distichum EtOH extract and its bioactive compound acteoside were evaluated. Screening of plants containing antioxidants is very important to widen the knowledge of possible sources that can counteract the effects of ROS. This will help prevent the occurrence of ROS-induced diseases such as aging, cancer, and other related diseases. The $\mathrm{DPPH},{ }^{\bullet} \mathrm{OH}$, and $\mathrm{O}_{2}{ }^{-}$ radical scavenging activities of $A$. distichum leaf $\mathrm{EtOH}$ extracts at a $250 \mu \mathrm{g} / \mathrm{mL}$ concentration were $88.32 \%, 94.48 \%$, and $14.36 \%$, respectively, whereas those of stem extracts at the same concentration were $88.15 \%, 88.99 \%$, and $15.36 \%$, respectively. The contents of acteoside in A. distichum leaves and stems were 162.11 and $29.68 \mathrm{mg} / \mathrm{g}$, respectively. Acteoside was identified as the main antioxidant compound in $A$. distichum leaves, which resulted in $\mathrm{DPPH},{ }^{\bullet} \mathrm{OH}$, and $\mathrm{O}_{2}{ }^{-}$radical scavenging activities of $82.84 \%$, $89.46 \%$, and $30.31 \%$, respectively, at a $25 \mu \mathrm{g} / \mathrm{mL}$ concentration. The results in our study demonstrated that $A$. distichum extract has a potent antioxidant activity which can be attributed to its high acteoside content. Moreover, our analyses have shown that the content of phenolic glycosides varies depending on the plant part analyzed. This study established the antioxidant qualities of the leaves and stems of A. distichium as an endemic plant to Korea that could be used a basis for developing therapeutic and nutritional products. Therefore, $A$. distichum showed possible use as an effective natural antioxidant for the prevention and treatment of oxidative stress-related diseases such as aging, cardiovascular, and neurodegenerative diseases.

Author Contributions: Analysis of A. distichum by HPLC/UV and LC-ESI/MS, H.-D.L.; antioxidant experiments, J.H.K. and Q.Q.P.; experimental materials and acteoside content, P.-M.J.; writing and editing, E.J.C.; acteoside preparation and writing, S.L. All authors have read and agreed to the published version of this manuscript.

Funding: This study was supported by a grant from the Natural Product Institute of Science and Technology (NIST-20-001), Anseong 17546, Republic of Korea.

Conflicts of Interest: The authors declare no conflict of interest. 


\section{References}

1. Park, J.H. Antioxidant activities and inhibitory effect on oxidative DNA damage of extracts from Abeliophylli distichi Folium. Korea J. Herbol. 2011, 26, 95-99.

2. Kang, U.C.; Chang, C.S.; Kim, Y.S. Genetic structure and conservation considerations of rare endemic Abeliophyllum distichum Nakai (Oleaceae) in Korea. J. Plant Res. 2000, 113, 127-138. [CrossRef]

3. Oh, H.; Kang, D.G.; Kwon, T.O.; Jang, K.K.; Chai, K.Y.; Yun, Y.G.; Chung, H.T.; Lee, H.S. Four glycosides from the leaves of Abeliophyllum distichum with inhibitory effects on angiotensin converting enzyme. Phytother. Res. 2003, 17, 811-813. [CrossRef] [PubMed]

4. Park, G.H.; Park, J.H.; Eo, H.J.; Song, H.M.; Woo, S.H.; Kim, M.K.; Lee, J.W.; Lee, M.H.; Lee, J.R.; Koo, J.S.; et al. The induction of activating transcription factor 3 (ATF3) contributes to anti-cancer activity of Abeliophyllum distichum Nakai in human colorectal cancer cells. BMC Complement Altern. Med. 2014, $14,487$. [CrossRef] [PubMed]

5. Li, H.M.; Kim, J.K.; Jang, J.M.; Cui, C.B.; Lim, S.S. Analysis of the inhibitory activity of Abeliophyllum distichum leaf constituents against aldose reductase by using high-speed counter current chromatography. Arch. Pharm. Res. 2013, 36, 1104-1112. [CrossRef] [PubMed]

6. Xiong, Q.; Kadota, S.; Tani, T.; Namba, T. Antioxidative effects of phenylethanoids from Cistanche deserticola. Biol. Pharm. Bull. 1996, 19, 1580-1585. [CrossRef]

7. Schlesier, K.; Harwat, M.; Böhm, V.; Bitsch, R. Assessment of antioxidant activity by using different in vitro methods. Free Radic. Res. 2002, 36, 177-187. [CrossRef]

8. Xie, J.H.; Wu, C.F. Effect of ethanolic extract of Cistanche deserticola on the contents of monoamine neurotransmitters in rat brain. Zhong Cao Yao 1993, 24, 417-419.

9. He, Z.D.; Lau, K.M.; Xu, H.X.; Li, P.C.; Pui-Hay, B.P. Antioxidant activity of phenylethanoid glycosides from Brandisia hancei. J. Ethnopharmacol. 2000, 71, 483-486. [CrossRef]

10. Li, J.; Wang, P.F.; Zheng, R.; Liu, Z.M.; Jia, Z. Protection of phenylpropanoid glycosides from Pedicularis against oxidative hemolysis in vitro. J. Med. Plant Nat. Prod. Res. 1993, 59, 315-317.

11. Zong, G.; He, W.; Wu, G.; Chen, M.; Shen, X.; Shi, M. Comparison between Cistanche deserticola Y. C. Ma and C. tubulosa (Shenk) Wight on some pharmacological actions. Zhongguo Zhong Yao Za Zhi 1996, 21, 436-437. [PubMed]

12. Pu, X.; Song, Z.; Li, Y.; Tu, P.; Li, H. Acteoside from Cistanche salsa inhibits apoptosis by 1-methyl-4-phenylpyridinium ion in cerebellum granule neurons. Planta Med. 2003, 69, 65-66. [CrossRef] [PubMed]

13. Birkofer, L.; Kaiser, C.; Thomas, U. Acteoside and neoacteoside: Zuckerester aus Syringa vulgaris. Z. Naturforsch. B 1968, 23, 1051-1058. [CrossRef] [PubMed]

14. Kwon, S.B.; Kang, H.J.; Kim, M.J.; Kim, J.H.; Shin, H.S.; Kim, K.S. Analysis on the components and safety evaluation of Abeliophyllum distichum Nakai leaves and stems. Korean J. Environ. Health 2014, 40, $234-244$. [CrossRef]

15. Nita, M.; Grzybowski, A. The role of the reactive oxygen species and oxidative stress in the pathomechanism of the age-related ocular diseases and other pathologies of the anterior and posterior eye segments in adults. Oxid. Med. Cell. Longev. 2016, 2016, 3164734. [CrossRef]

16. Floyd, R.A.; Carney, J.M. Free radical damage to protein and DNA: Mechanisms involved and relevant observations on brain undergoing oxidative stress. Ann. Neurol. 1992, 32, 22-27. [CrossRef]

17. Okawa, M.; Kinjo, J.; Nohara, T.; Ono, M. DPPH (1,1-diphenyl-2-picrylhydrazyl) radical scavenging activity of flavonoids obtained from some medicinal plants. Biol. Pharm. Bull. 2001, 24, 1202-1205. [CrossRef]

18. Lipinski, B. Hydroxyl radical and its scavengers in health and disease. Oxid. Med. Cell. Longev. 2011, 2011, 809696. [CrossRef]

19. Burton, G.J.; Jauniaux, E. Oxidative stress. Best Pract. Res. Clin. Obstet. Gynaecol. 2011, 25, $287-299$. [CrossRef]

20. Afanas'ev, I. Superoxide and nitric oxide in senescence and aging. Front. Biosci. 2009, 14, 3899-3912. [CrossRef]

21. Brieger, K.; Schiavone, S.; Miller, F.J., Jr.; Krause, K.H. Reactive oxygen species: From health to disease. Swiss Med. Wkly. 2012, 142, w13659. [CrossRef] [PubMed] 
22. Asensi, M.; Ortega, A.; Mena, S.; Feddi, F.; Estrela, J.M. Natural polyphenols in cancer therapy. Crit. Rev. Clin. Lab. Sci. 2011, 48, 197-216. [CrossRef] [PubMed]

23. Maxwell, S.R. Prospects for the use of antioxidant therapies. Drugs 1995, 49, 345-361. [CrossRef] [PubMed]

24. Hatano, T.; Edamatsu, R.; Hiramatsu, M.; Mori, A.; Fujita, Y.; Yasuhara, T.; Yoshica, T.; Okuda, T. Effects of the interaction of tannins with co-existing substances, VI. Effects of tannins and related polyphenols on superoxide anion radical, and on 1,1-diphenyl-2-picrylhydrazyl radical. Chem. Pharm. Bull. 1989, 37, 2016-2021. [CrossRef]

25. Gutteridge, J.M. Ferrous-salt-promoted damage to deoxyribose and benzoate. The increased effectiveness of hydroxyl-radical scavengers in the presence of EDTA. Biochem. J. 1987, 243, 709-714. [CrossRef]

26. Ewing, J.F.; Janero, D.R. Microplate superoxide dismutase assay employing a nonenzymatic superoxide generator. Anal. Biochem. 1995, 232, 243-248. [CrossRef]

27. Peng, C.; Wang, X.; Chen, J.; Jiao, R.; Wang, L.; Li, Y.M.; Zuo, Y.; Liu, Y.; Lei, L.; Ma, K.Y.; et al. Biology of ageing and role of dietary antioxidants. Biomed. Res. Int. 2014, 2014, 831841. [CrossRef]

28. Matés, J.M.; Pérez-Gómez, C.; de Castro, I.N. Antioxidant enzymes and human diseases. Clin. Biochem. 1999, 32, 595-603. [CrossRef]

29. Wang, W.; Zu, Y.; Fu, Y.; Efferth, T. In vitro antioxidant and antimicrobial activity of extracts from Morus alba L. leaves, stems and fruits. Am. J. Chin. Med. 2012, 40, 349-356. [CrossRef]

30. Chiou, W.F.; Lin, L.C.; Chen, C.F. Acteoside protects endothelial cells against free radical-induced oxidative stress. J. Pharm. Pharmacol. 2004, 56, 743-748. [CrossRef]

31. Cvetanović, A.; Zengin, G.; Zeković, Z.; Švarc-Gajić, J.; Ražić, S.; Damjanović, A.; Mašković, P.; Mitić, M. Comparative in vitro studies of the biological potential and chemical composition of stems, leaves and berries Aronia melanocarpa's extracts obtained by subcritical water extraction. Food Chem. Toxicol. 2018, 121, 458-466. [CrossRef] [PubMed]

32. Pan, N.; Hori, H. Antioxidant action of acteoside and its analogs on lipid peroxidation. Redox Rep. 1996, 2, 149-154. [CrossRef] [PubMed]

33. Li, M.; Zhou, F.; Xu, T.; Song, H.; Lu, B. Acteoside protects against 6-OHDA-induced dopaminergic neuron damage via Nrf2-ARE signaling pathway. Food Chem. Toxicol. 2018, 119, 6-13. [CrossRef] [PubMed]

34. Xia, D.; Zhang, Z.; Zhao, Y. Acteoside attenuates oxidative stress and neuronal apoptosis in rats with focal cerebral ischemia-reperfusion injury. Biol. Pharm. Bull. 2018, 41, 1645-1651. [CrossRef] [PubMed]

35. Chou, T.H.; Ding, H.Y.; Chan, L.P.; Liang, J.Y.; Liang, C.H. Novel phenolic glucoside, origanoside, protects against oxidative damage and modulates antioxidant enzyme activity. Food Res. Int. 2011, 44, 1496-1503. [CrossRef]

36. Li, H.L.; Chai, Z.; Shen, G.X.; Li, C.Y. Polyphenol profiles and antioxidant properties of ethanol extracts from Osmanthus fragrans (Thunb.) Lour. flowers. Pol. J. Food Nutr. Sci. 2017, 67, 317-325. [CrossRef]

37. Jang, T.W.; Choi, J.S.; Kim, H.K.; Lee, E.J.; Han, M.W.; Lee, K.B.; Kim, D.W.; Park, J.H. Whitening activity of Abeliophyllum distichum Nakai leaves according to the ratio of prethanol A in the extracts. Korean J. Plant Res. 2018, 31, 667-674.

38. Chen, C.H.; Lin, Y.S.; Chien, M.Y. Antioxidant and antihypertensive activities of acteoside and its analogs. Bot. Stud. 2012, 53, 421-429.

39. Jang, T.W.; Park, J.H. Antioxidant activity and inhibitory effects on oxidative DNA damage of callus from Abeliophyllum distichum Nakai. Korean J. Plant Res. 2018, 31, 228-236.

40. Ahn, J.; Park, J.H. Effects of Abeliophyllum distichum Nakai flower extracts on antioxidative activities and inhibition of DNA damage. Korean J. Plant Res. 2013, 26, 355-361. [CrossRef]

41. Jang, T.W.; Choi, J.S.; Park, J.H. Protective and inhibitory effects of acteoside from Abeliophyllum distichum Nakai against oxidative DNA damage. Mol. Med. Rep. 2020, 22, 2076-2084. [CrossRef] [PubMed]

Publisher's Note: MDPI stays neutral with regard to jurisdictional claims in published maps and institutional affiliations. 